\title{
Dissolved Organic Carbon Flux On Forest Toposequences in Jambi, Indonesia
}

\author{
Kukuh Murtilaksono ${ }^{\mathrm{a}}$, Syaiful Anwar ${ }^{\mathrm{b}}$, Arief Hartono ${ }^{\mathrm{a}}$, Sunarti ${ }^{\mathrm{b}}$, Yakov Kuzyakov ${ }^{\mathrm{c}}$, Gilang Sukma Putra ${ }^{\mathrm{d}}$, \\ Syamsul Arifin ${ }^{\mathrm{d}}$, Achmad Surya Adi Sustama ${ }^{\mathrm{d}}$ \\ a Dept. of Soil Science and Land Resource, IPB University, Darmaga Campus, Bogor, 16680, Indonesia \\ b Department of Agrotechnology, University of Jambi, Kampus Mendalo, Jambi, 36361, Indonesia \\ c Dept. of Soil Science of Temperate Ecosystems, University of Goettingen, Goettingen, 37077 Germany \\ ${ }^{\mathrm{d}}$ Graduate School, IPB University, Darmaga Campus, Bogor, 16680, Indonesia
}

\section{Article Info:}

Received: 16 - 01 - 2019

Accepted: 05 - 07 - 2019

Keywords:

DOC flux, slope, soil horizon.

Corresponding Author:

Kukuh Murtilaksono

Dept. of Soil Science and Land

Resource, IPB University;

Tel. +62-251-8629350;

$+628129271794$

Email:

kmurtilaksono@yahoo.com

How to cite (CSE Style $8^{\text {th }}$ Edition):

Murtilaksono K, Anwar S, Hartono A, Sunarti, Kuzyakov Y, Putra GS, Arifin S, Sustama ASA. 2019. Dissolved organic carbon flux on forest toposequences in Jambi, Indonesia. JPSL 9(4): 970-976. http://dx.doi.org/10.29244/jps1.9.4. 970-976.

\section{INTRODUCTION}

Dissolved organic matter (DOM) in soils can be indicated by its dissolved organic carbon (DOC) content. Dissolved organic matter is important in the biogeochemical process of carbon, nitrogen and phosphorous, soil formation, mineral weathering, and pollutant tranportation (Herbert and Bertsch 1995). DOC in the tropics is important because of its contribution to the soil organic matter formation. The role of DOC in soil carbon cycle of natural tropical forest is not well understood yet, and the data is still very limited. Excessive DOC which leaches over a long period of time will lead to a decrease in soil fertility and water body contaminations (Kalbitz et al. 2000; Fujii et al. 2009). In turn it would impact ecosystem equilibrium and local community livelihood as well. DOC flux in tropical forest is usually higher than that in subtropical forest due to the higher rate of litter decompoition in the tropical forest (Bond-Lamberty et al. 2004). The highest DOC concentration found in O horizon (Huang and Schoenau 1998). DOC will be transported into lower soil horizons by leaching process (Fujii et al. 2009). During this transportation, DOC can be fixed by soil particel or mineralized. DOC is very mobile in the soil and easily leached by water percolation. The DOC leached by water percolation in the soil profile will be affected by its position in a toposequence transect. The flux of DOC should be evaluated because their leaching will lead to soil deteorization. The objective of this research was to analize DOC flux within soil profiles in toposequence transects. 


\section{METHOD}

\section{Location and Time of Research}

This research had been carried out during May 2014 - April 2016 in Bukit Duabelas National Park, and May - December 2016 in Harapan Forest, Jambi Province, Indonesia. This research was integration from preceeding research in Bukit Duabelas National Park (Murtilaksono et al. 2016; Anwar et al. 2016) and succeeding research in Harapan Forest, Jambi, Indonesia.

Concentration of DOC was analized at the Laboratory of Plant Ecology, Soil and Nutrient Cycle, Center for Biology Research-LIPI Bogor as well as in the Laboratory of Department of Soil Scince and Land Resources, Faculty of Agriculture, Bogor Agricultural University, Indonesia.

Two research sites (within CRC990 research project) were selected, comprised of two toposequence transect (as replication). Its toposequence was devided into three plots (upper, middle, and lower slope). In total there were there were six profiles on $100 \%$ slope (Bukit Duabelas National Park) and six profiles on $45 \%$ slope (Harapan Forest).

\section{Soil Profiles and Instalation of Lysimeter}

The profiles and its horizons ( $\mathrm{AO}, \mathrm{AB}$, and $\mathrm{B})$ on the slope steepness were dug and described. The lysimeters were installed at those horizons (Figure 1). Installed lysimeters were connected into bottles (Tygon tubing). $\mathrm{CuCl}_{2}\left(0.05 \mathrm{mgL}^{-1}\right)$ solution was dropped into the bottles in order to protect leached water quality from organisms activity.

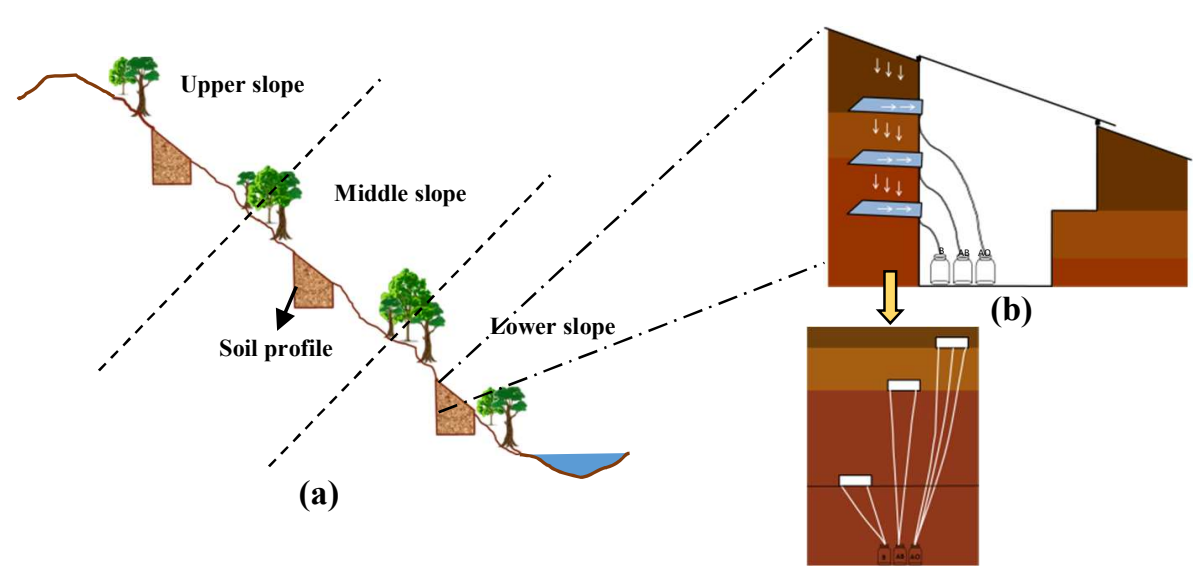

(c)

Figure 1 (a) Position of soil profiles, (b) Design of lysimeters instalation (side view), (c) Lysimeter instalation (front view).

\section{Collection and Storing of Leached Samples}

Leached water samples were collected using lysimeter periodically depends on rainfall. Volume of leached water samples were measured. About $500 \mathrm{ml}$ aliquod of the each leached water was sampled for laboratory analysis of DOC. The samples were kept cool to maintain their quality before laboratory analysis.

\section{Analysis of Leached Water Samples}

DOC concentration was measured using the method of NPOC. Microfibre filter Whatman GF/F $0.45 \mu \mathrm{m}$ pore size was used to separate DOC (Dissolved Organic Carbon) dan POC (Particulate Organic Carbon). The DOC in the filtrate was measured by TOC-VCPH SHIMADZU through combution at $680^{\circ} \mathrm{C}$ to convert organic carbon to $\mathrm{CO}_{2}$ gas that was detected by sensor of NDIR (non-dispersive infrared) to get concentration of DOC. 


\section{Flux of DOC and Data Analysis}

Total of DOC that eluviated within soil profile was calculated as follows:

\section{$\Sigma \mathrm{DOC}=\mathrm{V} . \mathrm{C}$}

where, $\Sigma$ DOC $=$ total of DOC $(\mathrm{mg}) ; \mathrm{V}=$ volume of percolated water $(\mathrm{L}) ; \mathrm{C}=$ concentration of $\mathrm{DOC}\left(\mathrm{mg} \mathrm{L}^{-1}\right)$

Flux of water was calculated as follows:

$$
\mathbf{J}_{\mathbf{w}}=\mathbf{V} / \mathbf{A} / \Delta \mathbf{t}
$$

where, $\mathrm{J}_{\mathrm{w}}=$ flux of water $\left(\mathrm{cm} \mathrm{day}^{-1}\right) ; \mathrm{V}=$ volume of percolated water $(\mathrm{L}) ; \mathrm{A}=$ area of lysimeter $\left(\mathrm{cm}^{2}\right) ; \Delta \mathrm{t}=$ periods of sampling (days)

Flux of DOC was determined based on total transport (bulk transport) of DOC transported within waterflow in soil pores $\left(\mathrm{J}_{\mathrm{lc}}\right)$ by equation:

$$
\mathbf{J}_{\mathbf{l c}}=\mathbf{J}_{\mathbf{w}} \cdot \mathbf{C}_{\mathbf{l}}
$$

where, $J_{1 \mathrm{c}}=$ fluks of solute tranport $\left(\mathrm{mg} \mathrm{cm}^{-2}\right.$ day $\left.^{-1}\right) ; J_{\mathrm{w}}=$ flux of water $\left(\mathrm{cm} \mathrm{day}^{-1}\right) ; \mathrm{C}_{1}=$ concentration of solute $\left(\mathrm{mg} \mathrm{L} \mathrm{L}^{-1}\right)$.

The average of each DOC fluxes between horizons and slope transects was compared using the statistical student t-test with a confidence level of $95 \%$.

\section{RESULT AND DISCUSSION}

\section{Bukit Duabelas National Park}

Land use of the research sites are secondary forest and dominated by Eusideroxylon zwageri, Shorea sp., Koompassia excelsa, Dyera costulata, Daemonorops draco, Agathis sp., and rattan (Calamus sp.). The soil texture generally was sandy clay loam $(50-70 \%$ of sand) within soil profiles, $0.13-0.15 \%$ of organic carbon content in AO horizon, 3.89-9.87 $\mathrm{cmol} \mathrm{kg}^{-1}$ of CEC, and classified as Acrisol or Ultisol.

The research result showed that annual DOC flux in the soil profiles from the lower slope was the highest (129.16 $\left.\mathrm{kgha}^{-1} \mathrm{year}^{-1}\right)$ and significantly different compared to the fluxes from the middle (74.20 $\left.\mathrm{kgha}^{-1} \mathrm{year}^{-1}\right)$ and the upper slope $\left(66.57 \mathrm{kgha}^{-1} \mathrm{year}^{-1}\right)$. On each slope, accumulated DOC flux was higher $\left(9.71-28.49 \mathrm{kgha}^{-}\right.$ $\left.{ }^{1}\right)$ during rainy season (November-April) than that during dry season ( $1.34-25.03 \mathrm{kgha}^{-1}$, May-October). The monthly highest DOC flux was on November and the lowest one was on October (Table 1). Meanwhile, Table 1 shows that annual DOC flux from AO soil horizon was higher (56.41-114.13 $\left.\mathrm{kgha}^{-1} \mathrm{year}^{-1}\right)$ and significantly different compared to the flux of $\mathrm{AB}$ (5.20-15.03 $\left.\mathrm{kgha}^{-1} \mathrm{year}^{-1}\right)$ and $\mathrm{B}$ (2.81-4.96 $\left.\mathrm{kgha}^{-1} \mathrm{year}^{-1}\right)$ horizons. The highest flux was from $\mathrm{AO}$ soil horizon of the lower slope position. In general, the higher the precipitation the higher the DOC flux particularly during rainy season. The calculated daily DOC flux was $0.595 \mathrm{kgha}^{-1}$ from the lower slope or $0.472 \mathrm{kgha}^{-1}$ from AO horizon during February 04 - April 28, 2016 (rainy season) while the flux was only $0.016 \mathrm{kgha}^{-1}$ or $0.013 \mathrm{kgha}^{-1}$ during dry season (August 05 - October 27, 2015). DOC would be largely accumulated from AO soil horizon of soil profile of the lower slope during rainy season.

The highest DOC flux is from O soil horizon and decreasing in lower soil horizon (Jury et al. 1989). DOC flux is affected by carbon content particularly lignin of litter and humus accumulation beside precipitation (Fujii et al. 2009; Fujii et al. 2011; Currie and Aber 1997).

\section{Harapan Forest}

Harapan forest has the similar soil type and vegetation to Bukit Duabelas National Park. The significant differences is on the land slope which the Harapan Forest has a lower slope (45\%) than that in the Bukit Duabelas National Park (100\%). 
Table 1 The annual flux and periodically amount of DOC based on soil horizons and soil profiles position of the Bukit Duabelas toposequence.

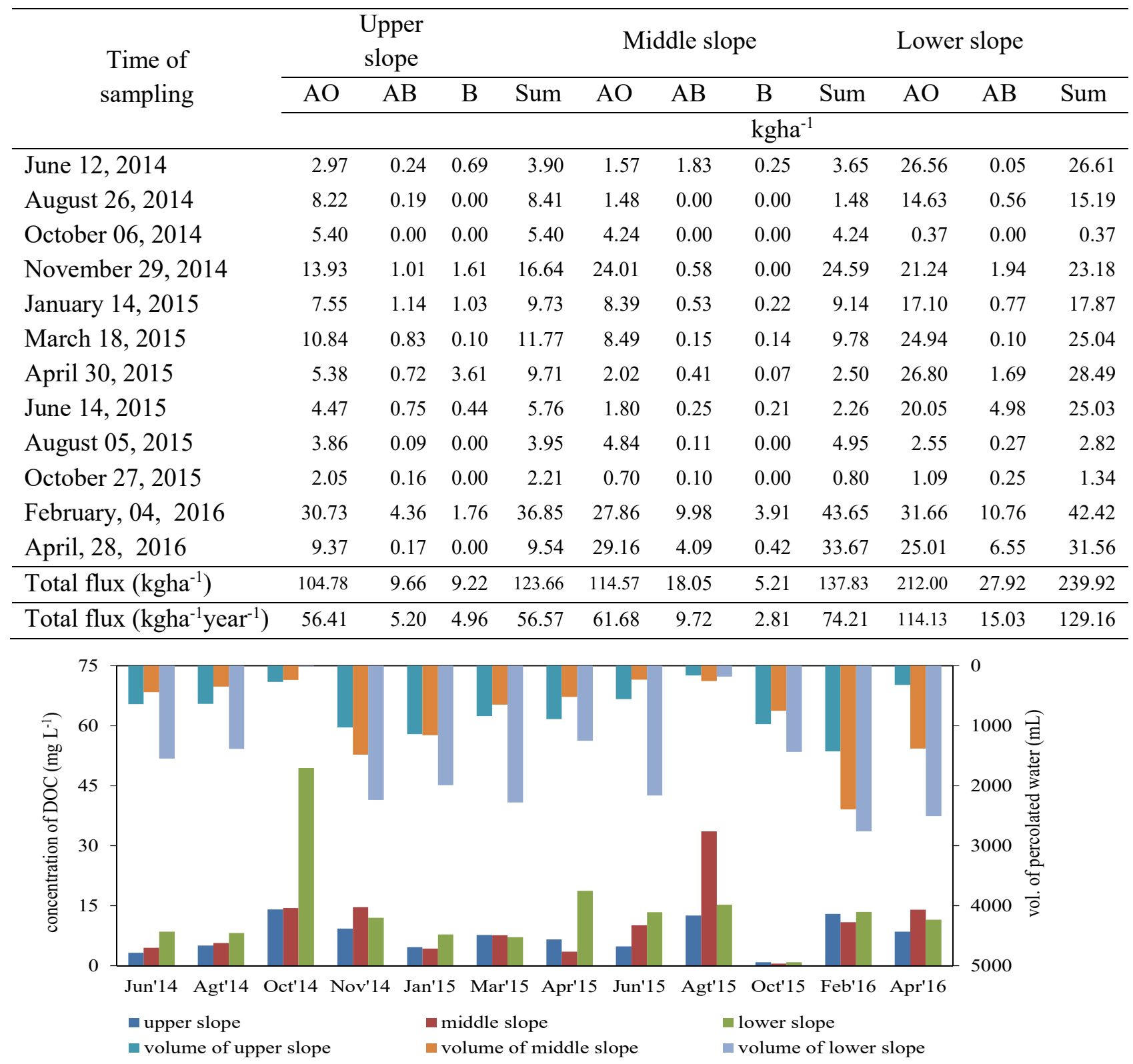

Figure 2 DOC concentration vs volume of percolated water based on soil profiles position of the toposequence.

The research result showed that annual DOC flux in the soil profiles from the lower slope was the highest (79.53 $\left.\mathrm{kgha}^{-1} \mathrm{year}^{-1}\right)$ followed by the fluxes from upper $\left(54.31 \mathrm{kgha}^{-1} \mathrm{year}^{-1}\right)$ and middle slope (33.15 $\mathrm{kgha}^{-1} \mathrm{year}^{-1}$ ). There was no significant differences of DOC flux between middle and upper slope. In Table 2, it can be seen that during the rainy season (October-December) on each slope transect, DOC accumulation had higher number than in the dry season (May-September). During the rainy season, the peak of DOC accumulation was the highest on the lower slope (11.77-16.24 $\left.\mathrm{kgha}^{-1}\right)$ followed by the upper slope (10.8512.64 $\left.\mathrm{kgha}^{-1}\right)$, and the lowest on the middle slope (1.51-9.01 $\left.\mathrm{kgha}^{-1}\right)$. Similar to the rainy season, the highest DOC accumulation in the dry season was on the lower slope (5-12.33 $\left.\mathrm{kgha}^{-1}\right)$, followed by the upper slope (2.21-7.36 $\left.\mathrm{kgha}^{-1}\right)$, and the middle slope (0.91-7.56 $\left.\mathrm{kgha}^{-1}\right)$. During the eight months of observation, the total DOC flux on the lower slope has a greater number where the lower slope has a DOC flux value of $56.22 \mathrm{kgha}^{-}$ ${ }^{1}$, followed by the middle slope of $23.43 \mathrm{kgha}^{-1}$, and the lowest on the upper slope of $38.39 \mathrm{kgha}^{-1}$. 
Table 2 The annual flux and periodically amount of DOC based on soil horizons and soil profiles position of the Harapan Forest toposequence.

\begin{tabular}{lrrrrrrrrrrrrr}
\hline \multicolumn{1}{c}{$\begin{array}{c}\text { Time of } \\
\text { sampling }\end{array}$} & \multicolumn{3}{c}{ Upper slope } & \multicolumn{4}{c}{ Middle slope } & \multicolumn{4}{c}{ Lower slope } \\
\cline { 2 - 13 } & \multicolumn{1}{c}{ AB } & B & Sum & AO & AB & B & Sum & AO & AB & B & Sum \\
\hline May 27, 2016 & 4.02 & 2.07 & 1.27 & 7.36 & 2.02 & 0.29 & 2.13 & 4.44 & 3.16 & 1.09 & 0.75 & 5.00 \\
August 04, 2016 & 1.79 & 0.35 & 0.07 & 2.21 & 0.91 & 0.00 & 0.00 & 0.91 & 5.20 & 5.45 & 0.24 & 10.89 \\
September 03, 2016 & 2.85 & 0.64 & 1.83 & 5.33 & 6.95 & 0.00 & 0.61 & 7.56 & 6.54 & 5.79 & 0.00 & 12.33 \\
October 07, 2016 & 8.30 & 1.52 & 1.03 & 10.85 & 1.13 & 0.00 & 0.38 & 1.51 & 8.56 & 7.68 & 0.00 & 16.24 \\
December 27, 2016 & 10.27 & 0.13 & 2.23 & 12.64 & 5.81 & 1.81 & 1.39 & 9.01 & 11.15 & 0.24 & 0.38 & 11.77 \\
\hline Total flux (kg/ha) & 27.24 & 4.72 & 6.44 & 38.39 & 16.82 & 2.10 & 4.51 & 23.43 & 34.60 & 20.25 & 1.37 & 56.22 \\
\hline Total flux (kg/ha/year) & 38.53 & 6.67 & 9.11 & 54.31 & 23.80 & 2.97 & 6.38 & 33.15 & 48.96 & 28.64 & 1.93 & 79.53 \\
\hline
\end{tabular}

During both dry season and rainy season, the accumulation amount of DOC flux was the highest in the $\mathrm{AO}$ horizon. While the $\mathrm{AB}$ and $\mathrm{B}$ horizons have fluctuated amount each month. On the upper slope, the highest DOC flux accumulation was in December $\left(10.27 \mathrm{kgha}^{-1}\right)$ and the lowest was in August $\left(1.79 \mathrm{kgha}^{-1}\right)$. The middle slope had the highest DOC accumulation in September $\left(6.95 \mathrm{kgha}^{-1}\right)$ and the lowest in August $(0.91$ $\left.\mathrm{kgha}^{-1}\right)$. and the highest downward slope of DOC accumulation occurred in December $\left(11.15 \mathrm{kgha}^{-1}\right)$ and the lowest in May (3.16 $\left.\mathrm{kgha}^{-1}\right)$. During 8 months of observation, the accumulation of DOC flux at the AO horizon $\left(78.66 \mathrm{kgha}^{-1}\right)$ was significantly $(\alpha=95 \%)$ higher than the AB horizon $\left(27.06 \mathrm{kgha}^{-1}\right)$ and B $\left(12.32 \mathrm{kgha}^{-1}\right)$. Whereas between the $\mathrm{AB}$ and $\mathrm{B}$ horizons there was a slight difference in the DOC flux value but the value was not statistically significant. As explained earlier, the high of DOC flux at the AO horizon due to high content of soil C-organic matter as a result from the decomposition of litter which accumulates a lot in the upper soil layer (O horizon).

\section{Difference of DOC Flux between Two Sites}

Based on the previous data showed on Table 1 dan Table 2, there was a significant differences on DOC flux between Bukit Duabelas National Park (BDNP) and Harapan Forest (HF). The major difference is found on the total ammount of DOC accumulated both on the soil horizon and toposequence. Based on data showed on Figure 3, it can be found that between the two observation sites had different annual DOC flux both between horizons and on each slope transect. In both locations, the AO Horizon had the highest annual DOC value followed by the AB horizon and B. At BDNP the annual DOC flux value had the highest number on the lower slope (129.16 kgha $\left.\mathrm{year}^{-1}\right)$, followed by the middle slope (74.21 $\left.\mathrm{kgha}^{-1} \mathrm{year}^{-1}\right)$, and upper slope (66.57 kgha${ }^{1}$ year $\left.{ }^{-1}\right)$. Whereas the HF annual DOC flux was highest on the lower slope ( $\left.79.53 \mathrm{kgha}^{-1} \mathrm{year}^{-1}\right)$, the upper slope $\left(54.31 \mathrm{kgha}^{-1} \mathrm{year}^{-1}\right)$, and the middle slope $\left.\mathrm{kgha}^{-1} \mathrm{year}^{-1}\right)$. In general, there are similarities in the pattern of annual DOC fluxes between two locations. Both BDNP and HF annual DOC fluxes on the lower slope has the highest amount (significant at $\alpha=95 \%$ ) compared to the middle and the upper slopes. The difference in the two locations was found on total amount of annual DOC fluxes. On each position of slope transect, the annual DOC fluxes of BDNP was higher than HF since the slope of BDNP was steeper than the HF's one. On the middle and lower slopes BDNP's annual DOC value was significantly greater ( $\alpha=95 \%)$ than that on the HF. Although on the upper slope there was no statistically significant differences, BDNP's annual DOC value was still greater than HF.

Many factors influence the amount of the DOC fluxes on the soil horizon, including soil C-organic content, type of vegetation, and soil properties (Serrano et al. 2016), and slope (Chibuike 2018). Since soil and vegetation type in both locations was identic, main factors that greatly influence the difference of DOC fluxes are C-organic soil content and land slope. The laboratory analysis result showed that C-organic content in the upper soil horizon of BDNP ranged from $2.4-3.67 \%$, while those in HF ranged from $2.19-2.67 \%$. It can be concluded that $\mathrm{C}$-organic content in BDNP are higher than HF. The high $\mathrm{C}$-organic level of the soil can trigger a high amount of DOC due to a greater source of C-organic (Gonet 2006). Field observation result 
showed that in BDNP the slope was greatly steeper (100\%) compared to HF which was only $45 \%$. The slope greatly affected the amount of DOC that accumulates more on the lower than upper slope.

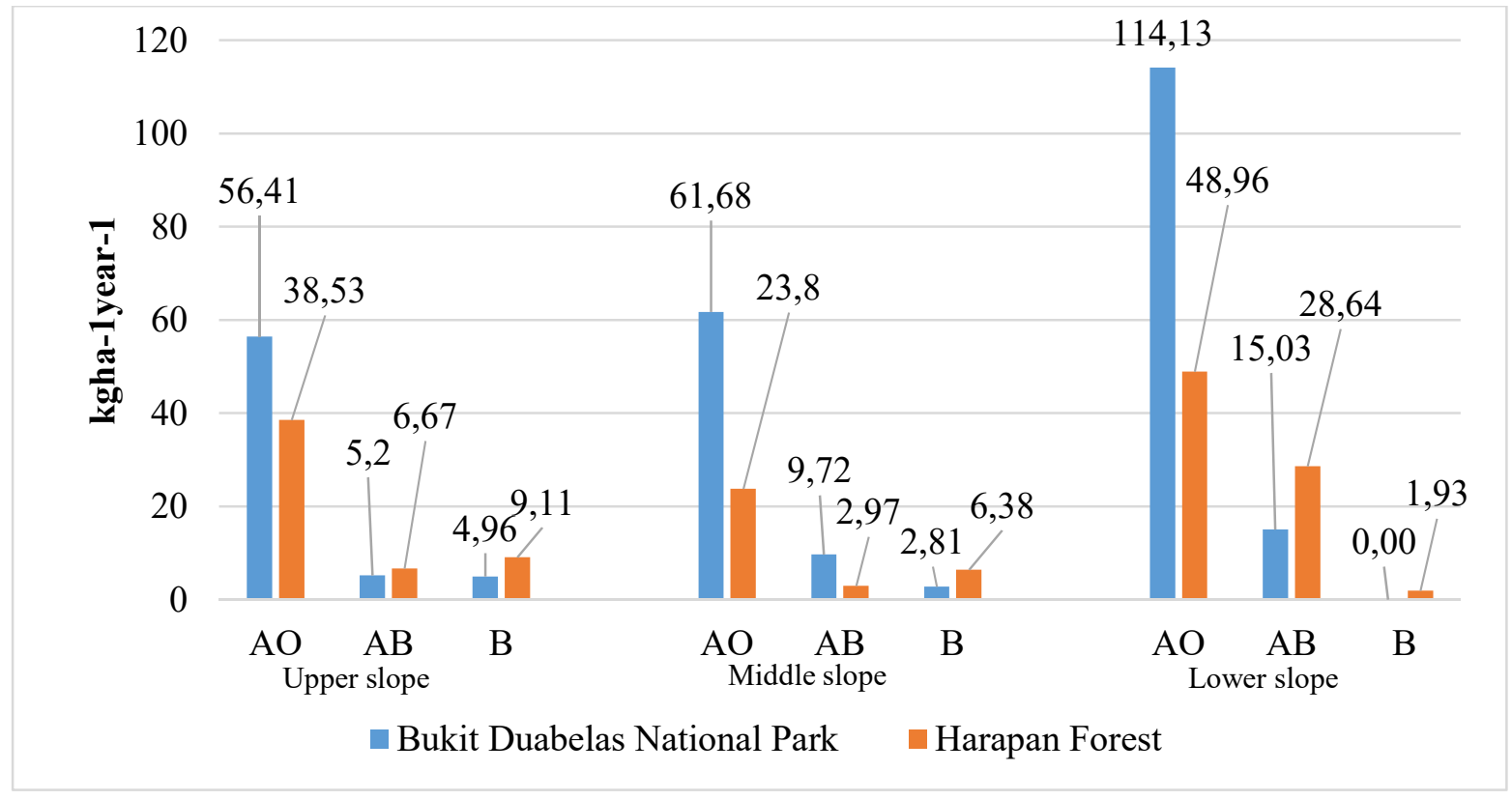

Figure 3. Annual DOC fluxes between two sites (Bukit Duabelas National Park and Harapan Forest).

\section{CONCLUSIONS}

Based on the study of DOC fluxes within soil profiles on a toposequence transect of Bukit Dua Belas National Park and Harapan Forest, the major conclusions are as follows :

1. Both in Bukit Dubelas National Park and Harapan Forest the amount and flux of DOC in soil horizons of the lower slope was significantly higher than that of the middle and the upper slopes. The DOC of the middle slope, however, was not significantly higher on middle than that on the upper slope.

2. Amount and flux of DOC of AO soil horizon was significantly higher than that of $A B$ and $B$ soil horizons. The DOC of $\mathrm{AB}$ horizon, however, was not significantly higher than that on $\mathrm{B}$ soil horizon.

3. DOC was largely accumulated in AO soil horizon of soil profile on lower slope during rainy season than that on the dry season.

4. The total amount of DOC flux in the Bukit Duabelas National Park was significantly higher than that in the Harapan forest.

5. DOC flux Both in the Bukit Duabelas National Park and Harapan Forest had the highest accumulated amount at lower slope and $\mathrm{AO}$ horizon.

\section{ACKNOWLEDGEMENT}

Authors thanks to ABS fund of CRC990 research project and research grand of Ministry of Research, Technology, and Higher Education, Republic of Indonesia.

\section{REFERENCES}

Anwar S, Murtilaksono K, Hartono A, Putra GS. 2016. Fluxes of dissolved organic carbon and nutrient leaching in a toposequent of Bukit Dua Belas National Park, Indonesia. International Journal of Advances in Science, Engineering and Technology. 4(4). Iraj.in/journal/IJESEAT/Volume.php?volume_id=497. 
Bond-Lamberty B, Wang C, Gower ST. 2004. A global relationship between the heterotrophic and autotrophic components of soil respiration?. Global Change Biology. 10: 1756-1766. Books.google.co.id/books?id=IHwIAQAAMAAJ.

Chibuike G, Burkitt L, Bretheron M, Arbestain MC, Singh R, Bishop P, Hedley C, Roudier P. 2018. The effect of soil type and slope on the dissolved organic carbon concentration and denitrification capacity of a hill country sub-catchment. Farm Environmental Planning - Science, Policy and Practice. Occasional Report No. 31. Fertilizer and Lime Research Center, Massey University, New Zeland.

Currie WS, Aber JD. 1997. Modeling leaching as a decomposition process in humid montane forests. Ecology. 78: $1844-1860$.

Fujii K, Hartono A, Funakawa S, Uemura M, Kosaki T. 2011. Fluxes of dissolved organic carbon in three tropical secondary forests developed on serpentine and mudstone. Geoderma. 163: 119-126.

Fujii K, Uemura M, Hayakawa C, Funakawa S, Sukartiningsih, Kosaki T, Ohya S. 2009. Fluxes of dissolved organic carbon in two tropical forest of East Kalimantan Indonesia. Geoderma. 152: 127-136.

Gonet SS, Debska B. 2006. Dissolved organic carbon and dissolved nitrogen in soil under different fertilization treatments. Plant Soil Environment. 52: 55-63. doi.org/10.17221/3346-PSE.

Herbert BE, Bertsch PM. 1995. Characterization of dissolved and colloidal organic matter in soil solution: A review. In Carbon forms and functions in forest soils. J.M. Kelly, W. W. McFee (ed.). SSSA, Madison, WI, pp.63-88.

Huang WZ, Schoenau LL. 1998. Fluxes of water-soluble nitrogen and phosphorous in the forest floor and surface mineral soil of a boreal aspen stand. Geoderma. 81: 251-264. doi.org/10.1016/S00167061(97)00092-X.

Jury WA, Gardner WR, Gardner WH. 1991. Soil Physics. New York: John Wiley \& Sons, Inc.

Kalbitz K, Solinger S, Park JH, Michalzik B, Matzner E. 2000. Controls on the dynamics of dissolved organic matter in soils: A review. Soil Science. 165:277-304. doi: 10.1097/00010694-200004000-00001.

Murtilaksono K, Anwar S, Hartono A, Sunarti, Kuzyakov Y. 2016. Dissolved organic carbon flux on a toposquent in Bukit Duabelas National Park, Indonesia. International J. of Advances in Science Engineering and Technology 4:45-47. www.researchgate.net. Citation-318360272.txt

Serrano MC, Pannatier EG, Vicca S, Luyssaert S, Jonard M, Ciais P, Guenet B, Gielen B, Panuelas J, Sardans J, Waldner P, Etzold S, Cecchini G, Clarke N, Galic N, Gandois L, Hansen K, Johnson J, Klinck U, Lachmanova Z, Lindroos AJ, Meesenburg H, Nieminen H, Sanders TGM, Sawicka K, Seidling W, Thimonier A, Vanguelova E, Verstraeten A, Vesterdal L, Janssens IA. 2016. Trends in soil solution dissolved organic carbon (DOC) concentrations across European forests. Biogeoscience. 13: 5567-5585. doi.org/10.5194/bg-13-5567-2016. 